\title{
Pemanfaatan E-Commerce bagi Kelompok Pendidik SDIT Fatahillah Kebagusan di Era Pandemi
}

\author{
Tuti Handayani $^{1}$, Alusyanti Primawati ${ }^{2}$ \\ ${ }^{1,2}$ Program Studi Teknik Informatika, FTIK, Universitas Indraprasta PGRI \\ Jl. Nangka Raya No.58C Jagakarsa, Jakarta, Indonesia \\ e-mail: ${ }^{1}$ tuti.hani80@gmail.com, ${ }^{2}$ alus.unindra23@gmail.com
}

\begin{abstract}
Abstrak
Pada era pandemi, situasi diberlakukannya PSSB pada setiap wilayah untuk mencegah penyebaran Covid-19 memberikan dampak diberbagai kalangan. Salah satu dampaknya adalah pemberhentian pegawai, tutupnya toko offline pada beberapa waktu, sepinya pengunjung toko, perekonomian pedagan menurun akibat daya beli masyarakat berkurang. Akan tetapi di sisi lain, situasi ini meningkatkan penggunaan media Online sebagai media untuk memenuhi kebutuhan tanpa harus keluar rumah. Salah satunya adalah Platform E-commerce seperti Tokopedia, Bukalapak, Shoppe, dll. Sedangkan media sosial seperti Instagram dan Facebook masih menjadi media popular yang digunakan untuk pemasaran produk. Mitra dalam kegiatan pengabdian masyarakat ini adalah kelompok pendidik SDIT Fatahilla. Persamasalah mitra adalah belum menggunakan secara produkstif Platform E-commerce yang sudah popular saat ini. Mitra cenderung menggunakan untuk melakukan pembelian kebutuhan. Solusi yang kami tawarkan adalah mengenalkan manfaat lain e-commerce sebagai media usaha mandiri di era pandemi sehingga mitra memperoleh keterampilan untuk memulai usaha online dirumah untuk menambah pendapatan keluarga. Hasil dari kegiatan ini mitra memperoleh pengetahuan berupa informasi bagaiaman memulai bisnis online bagi pemula. Dan topik e-commerce merupakan hal baru yang diperoleh mitra sehingga menumbuhkan kemauan mitra untuk mulai memanfaatkan e-commerce secara produktif.
\end{abstract}

Kata Kunci: e-commerce, SDIT Fatahillah, era pandemi, media usaha mandiri

\section{Abstract}

In the pandemic era, the situation of implementing the PSSB in each region to prevent the spread of Covid-19 had an impact on various circles. One of the impacts were employee dismissal, the closure of offline stores at some time, the lack of shop visitors, and the merchant economy has declined due to reduced purchasing power. But on the other hand, this situation increases the use of online media as a medium to meet needs without having to leave the house. One of them is E-commerce Platforms such as Tokopedia, Bukalapak, Shoppe, etc. Meanwhile, social media such as Instagram and Facebook are still popular media used for product marketing. Partners in this community service activity are the SDIT Fatahillah educator group. The problem with partners was not used productively E-commerce Platform which is already popular today. Partners tend to use to make necessity purchases. The solution we offer were to introduce other benefits of e-commerce as an independent business medium in the pandemic era so that partners gain the skills to start an online business at home to increase family income. The results of this activity partners gain knowledge about information like how to start an online business for beginners. And the topic of e-commerce was something new that was

This work is licensed under a Creative Commons Attribution-ShareAlike 4.0 International License.

Published by LPPM Universitas Bina Sarana Informatika 
obtained by partners, so that it fosters the willingness of partners to start using e-commerce productively.

Keywords: e-commerce, SDIT Fatahillah, pandemic period, independent business media.

\section{Pendahuluan}

Di era pandemi ini, saat semua toko offline pada merugi karena situasi wabah covid yang mengharuskan pemerintah memberlakukan PSBB dan banyak perusahaan yang memberhentikan karyawannya, oleh karena itu setiap orang harus mempunyai ide kreatif untuk mendapatkan penghasilan tambahan. Salah satu solusi yang memiliki peran penting bagi pereknomian Indonesia selama pandemi Covid-19 adalah e-commerce (Ayu \& Lahmi, 2020). Keberhasilan e-commerce didukung oleh pengunaan jejaring sosial. Pengguna jejaring sosial mengalami peningkatan di tahun 2020 sehingga ada indikasi peningkatan yang linear terhadap transaksi online selama pandemi, hal ini disebabkan kebutuhan utama publik dapat terpenuhi tanpa melakukan belanja langsung karena masyarakat takut berbelanja secara langsung (Syamsidarti Laming, 2020). Situasi saat ini, tempat umum seperti toko ritel offline dihindari oleh masyarakat sehingga penjualan online mengalami peningkatan di beberapa sektor (Sudaryono et al., 2020).

Menurut Sudaryono et al (2020), pandemi berhasil menciptakan transformasi bisnis ke ranah online yang terpaksa harus dilakukan oleh para pelaku bisnis tradisional seperti UMKM, Pasar Tradisional serta pelaku usaha makanan dan minuman, hal ini dilakukan sebagai strategi pemasaran untuk menaikan omset dimasa pandemi. Berdasarkan hal tersebut maka terbukanya peluang besar pada bidang e-commerce untuk dimanfaatkan oleh masyarakat disemua kalangan, khususnya pada masa pandemin saat ini. Kanal daring yang memberikan tempat bagi kelompok atau individu untuk berkomunikasi adalah Media Soial untuk berbagi konten, dan berkolaborasi secara digital, membuka forum, dan lainnya (Hadiwinata et al., 2020). Oleh sebab itu media sosial merupakan tempat yang tepat untuk mulai untuk melakukan pemasaran produk untuk memulai bisnis online. Media sosial yang popular untuk berdagang adalah Instagram, Facebook, Tik Tok dan Youtube.

BPS 2019 tentang statistika e-commerce dalam Orinaldi (2020) menunjukan ekstensi $e$ commerce sebelum pandemi yaitu $84,92 \%$ pelaku usaha belum menggunakan e-commerce sedangkan 15,08\% menggunakan e-commerce dikarenakan 70,89\% pelaku usaha lebih nyaman berjualan secara offline. Berdasarkan hal tersebut maka diungkapkan menjadi alasan banyaknya pelaku usaha gulung tingkar pada saat menghadapi pandemi. Situasi pandemi menyebabkan $e$ commerce sangat dibutuhkan sebagai media penjulan dan pemasaran. Berdasarkan latar belakang perkembangan peranan e-commerce pada era pandemi maka ditemukan adanya kebutuhan untuk mempernalkan dan melatih masyarakat untuk memanfaatkan e-commerce tidak hanya sebagai konsumen melainkan sebagai penjual. Hal ini memberikan tantangan untuk menumbuhkan dan meningkatkan jiwa wirausaha masyarakat sehingga dapat meningkatkan pendapatan dalam keluarga yang mengalami dampak pandemi sekaligus memulihkan perekonomian negara. Sosialisasi dan penyuluhan atau pelatihan penggunaan e-commerce menjadi rangkaian kegiatan pengabdian masyarakat yang popular saat inii, hal ini dilakukan sebagai wujud mendukung memulihkan perekonomian pemerintah.

Pada kegiatan pengabdian masyarakat sebelumnya yang telah dilakukan oleh Sugiarti et al (2020) yang bertujuan mengenalkan peranan e-commerce untuk dimanfaatkan oleh UMKM untuk mempeluas pangsa pasar dan hasil yang diperoleh yaitu produk yang dijual menggunakan 
e-commerce seperti Tokopedia, Bukalapak, Shopee, Lazada dan Bliblu mengalami peningkatan signifikan dari periode Juli - Desember 2019 ke Januari - Mei 2020 sehingga disarankan bahwa selanjutnya UMKM harus lebih fokus mengelola penjualan melalui e-commerce supaya lebih optimal.

Tahun 2019, Priyowidodo et al (2019) melakukan kegiatan pengabdian masyarakat bersama mitra GPDI Sejahtera Batu Malang yang bertemakan pemberdayaan perempuan dalam memahami komunikasi pemasaran pada media online (konsep e-commerce). Kegiatan direalisasikan melalui pelatihan media informasi, komunikasi pemasaran dan edukasi $e$ commerce dalam konsep shopping online. Hal tersebut merupakan solusi untuk menyelesaikan permasalahan mitra yaitu tersedianya cukup waktu dalam menggunakan teknologi bagi kaum perempuan tetapi kurang produktif dalam pemanfaatannya. Selain dikalangan kaum perempuan digerja, pemberdayaan e-commerce juga dilakukan untuk peningkatan wirausaha santri dan menghasilkan kenaikan omset saat Santri mengimplementasikan $e$-commerce dalam usaha yang dikerjakan santri (Kaban et al., 2020).

Kegiatan pengabdian masyarakat sebelumnya yang relevan menunjukan perlunya kegiatan ini dilakukan untuk berbagai kalangan. Kebutuhan akan meningkatkan produktifitas selama dirumahkan saat pandemi sebagai cara meningkatkan pendapatan juga menjadi kebutuhan yang diperlukan oleh mitra kami dari SDIT Fatahillah Kebagusan. Terlepas dari betapa pentingnya e-commerce, tidak dipungkiri bahwa dalam melakukan kegiatan sehari-hari masih belum menggunakan e-commerce secara maksimal. Kebanyakan guru dan orang tua siswa hanya menggunakan e-commerce untuk membeli kebutuhan yang ada diskonnya ataupun barang yang susah dicari di toko offline. Padahal mereka dapat menggunakan e-commerce ini sebagai media usaha mandiri berbasis online untuk mendapatkan penghasilan tambahan. Oleh karena itu, kami menawarkan solusi bagi para guru dan orang tua siswa SDIT Fatahillah dengan memberikan pelatihan pemanfaatan e-commerce sebagai media usaha mandiri berbasis online di era pandemi.

Menyikapi permasalahan yang telah diuraikan di atas dan dalam rangka pengabdian masyarakat, kami mengusulkan pengabdian masyarakat yang bertema "PKM Kelompok Pendidik SDIT Fatahillah Kebagusan" dengan materi "Pelatihan pemanfaatan e-commerce sebagai media usaha mandiri berbasis online di era pandemi."

Mitra pengabdian masyarakat kami adalah kelompok pendidik SDIT Fatahillah Kebagusan. Kelompok pendidik diantaranya guru dan orang tua siswa. Beberapa permasalahan yang sedang dihadapi oleh mitra, diantaranya adalah :

1. Mitra menggunakan e-commerce hanya untuk pembelian kebutuhan yang tidak ada di toko offline.

2. Minimnya pengetahuan mitra dalam penggunaan e-commerce sebagai media usaha mandiri berbasis online.

3. Kurangnya pengetahuan mitratentang manfaat e-commerce.

Tujuan dari kegiatan pengabdian masyarakat ini adalah:

1. Manfaat e-commerce sebagai media usaha mandiri berbasis online.

2. Penggunaan $e$-commerce untuk mendapatkan penghasilan tambahan mitra.

3. Pengetahuan orang tua siswa masih minim dalam penggunaan e-commerce.

Kegiatan Pengabdian Masyarakat yang telah dilaksanakan merupakan Program Kemitraan Masyarakat. Mitra sasaran program ini adalah para guru dan orang tua siswa SDIT Fatahillah 
yang dilaksanakan dalam bentuk kegiatan pelatihan untuk meningkatkan penggunaan teknologi, yaitu:

1. Pemanfaatan $e$-commerce sebagai media usaha mandiri berbasis online.

2. Penggunaan $e$-commerce untuk kegiatan sehari-hari.

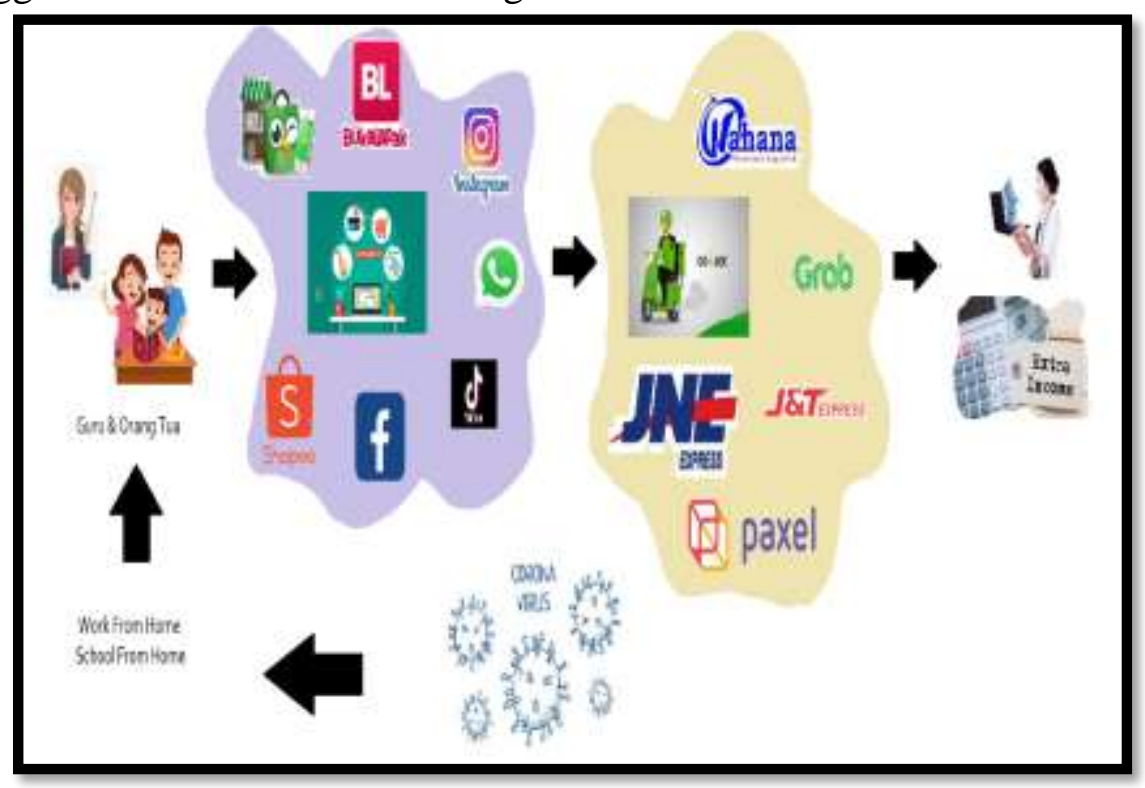

Gambar 1. Penerapan e-Commerce sebagai Media Usaha Mandiri

\section{Metode}

Sesuai dengan tujuan pusat pengabdian masyarakat dalam analisis situasi diatas, maka Universitas Indraprasta PGRI sebagai salah satu institusi perguruan tinggi melalui kegiatan pengabdian kepada masyarakat diharapkan dapat berperan aktif dalam menyebarluaskan IbM sebagai produk yang telah diteliti dan dimanfaatkan untuk mencapai sasaran tersebut. Metode yang digunakan pada kegiatan pengabdian masyarakat adalah Sosialisasi Platform e-commerce melalui Daring dengan tahapan sebagai berikut:

1. Analisis Kebutuhan Mitra

Tim menjelaskan kebutuhan yang diperlukan masyarakat saat ini dalam menghadapi pandemi berdasarkan analisi situasi dan kebutuhan tersebut selinier dengan kebutuhan mitra saat ini. Pembelajaran jarak jauh memberikan peluang bagi kelompok pendidik baik guru atau orang tua untuk leibh meningkatkan produktifitas sehingga memperoleh pendapatan tambahan di era pandemi melalui perkembangan e-commerce.

2. Koordinasi Pelaksanaan melalui Zoom Meeting

Kegiatan pengabdian masyarakat ini dilaksanakan secara daring dengan Zoom Meeting menggunakan metode presentasi, diskusi, atau kombinasi antara metode tersebut pada hari Jumat, tanggal 22 Januari 2021 pada pukul 13.45 s.d 15.00. 


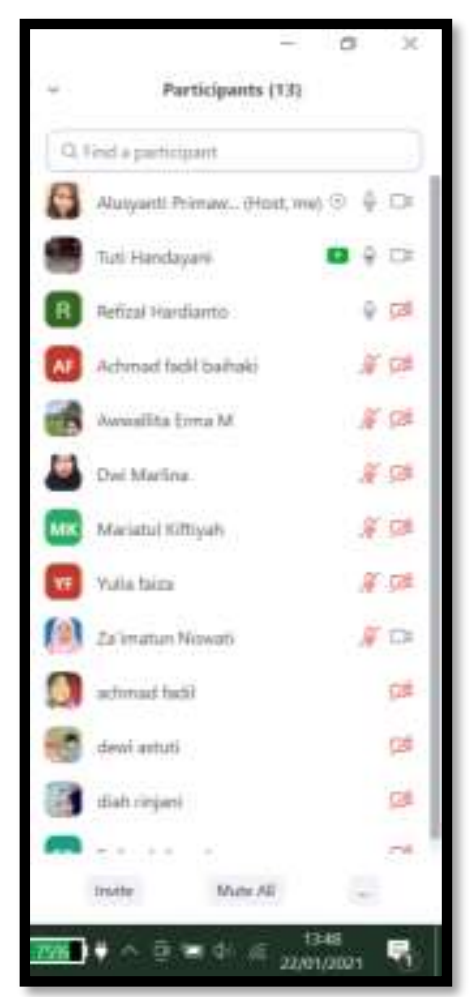

Gambar 2. Kehadiran Peserta

\section{Sosialisasi Penerapan Platform E-Commerce}

Platform e-commerce yang dijelaskan kepada mitra adalah Tokopedia dan Shopee yang dilengkapi dengan media pemasaran menggunakan Instagram dan Ekspedisi yang mendukung e-commerce seperti JNE, J\&T, PAXEL, Wahana, dll.

4. Pelatihan Membuka Toko pada E-Commerce

Pada tahapan ini, kami menjelaskan kepada mitra langkah-langkah pendaftaran toko pada platform e-commerce yang dipilih. Tidak hanya cara mendaftar tetapi juga menjelaskan bagaimana melakukan transaksi dengan aman.

\section{Diskusi}

Kemudian untuk memperdalam materi diberikan contoh dan dibuka kesempatan untuk tanya jawab bagi peserta pelatihan.

\section{Hasil dan Pembahasan}

Kegiatan pengabdian masyarakat telah terlaksana dengan dihadiri peserta dari mitra SDIT Fatahillah Kebagusan. Pelaksanaan dilakukan secara daring melalui media Zoom Meeting sebanyak 3 sesi dengan masing-masing sesi memiliki waktu 40 menit. Sesi 1 pemaparan materi dari Tim 1. Tim 1 adalah tim pengabdian masyarakat dari Teknik Informatika Universitas Indraprasta dengan tema yang berbeda yaitu Excel dan Google Form, sedangkan kami adalah Tim 2 dengan asal yang sama yaitu Dosen Teknik Informatika Universitas Indraprasta PGRI dengan tema tentang e-commerce pada masa pandemi. Sesi 3 merupakan sesi dibukanya diskusi antar mitra dan tim pengabdian masyarakat. Pemaparan hasil kegiatan ini berfokus pada hasil kegiatan tim kami yaitu tim 2 . Tabel 1 berikut memaparkan kendala terlaksanakan kegiatan beserta solusi penyelesaiannya segingga kegiatan dapat berlangsung dengan baik. 
Tabel 1. Kendala dan Penyelesaian Realisasi

Kegiatan Pengabdian Kepada Masyarakat

\begin{tabular}{|c|c|c|}
\hline No & Kendala & Penyelesain \\
\hline 1 & $\begin{array}{l}\text { Penjadwalan pelaksanaan diundur sebanyak } 2 \text { kali } \\
\text { karena bentroknya kegiatan mitra dengan tim atau } \\
\text { sebaliknya }\end{array}$ & $\begin{array}{l}\text { Setelah } 2 \text { kali undur, sampai pada kesepakatan } \\
\text { dilaksanakan pada tanggal } 22 \text { Januari } 2021\end{array}$ \\
\hline 2 & $\begin{array}{l}\text { Mitra berharap pelaksanaan dilakukan tatap muka, } \\
\text { dan tim menyetujui akan tetapi dikarenakan } \\
\text { meningkatnya penderita Covid } 19 \text { sehingga } \\
\text { pertemuan dibatalkan dengan kesepakatan } \\
\text { bersama. }\end{array}$ & $\begin{array}{l}\text { Pelaksanaan disepakati bersama menggunakan } \\
\text { Zoom Meeting. }\end{array}$ \\
\hline 3 & $\begin{array}{l}\text { Tim Abdimas belum memiliki akun premium } \\
\text { Zoom Meeting sehingga batas waktu pertemuan } \\
\text { hanya } 40 \text { menit. }\end{array}$ & $\begin{array}{l}\text { Pelaksanaan dibuat } 3 \text { sesi melalui Zoom } \\
\text { Meeting dan link masing-masing sesi sudah } \\
\text { dibagikan sebelum acara berlangsung. }\end{array}$ \\
\hline 4 & $\begin{array}{l}\text { Materi yang dipaparkan cukup banyak sehingga } \\
\text { membutuhkan waktu yang cukup banyak }\end{array}$ & $\begin{array}{l}\text { Mempersingkat bagian konteksual dan langsung } \\
\text { pada materi penerapan serta implementasi e- } \\
\text { commerce. }\end{array}$ \\
\hline
\end{tabular}

Pada sesi sosialisasi pengetahuan umum tentang Platform e-commerce dikalangan mitra sudah popular seperti Tokopedia, Shopee, Bukalapak, Lazada dan lainnya. Tim pelaksana pengabdian masyarakat menjelaskan sistem yang terintegrasi pada platform e-commerce yaitu:

1. Profil Toko

Platform e-commerce menyediakan semua informasi dari toko untuk dapat diketahui pembeli. Penjual wajib memberikan informasi yang sebenar-benarnya saat bergabung dengan platform e-commerce.

2. Katalog

Semua platform e-commerce menyedida katalog yang berisikan produk yang dijual oleh penjual atau toko onlin yang tergabung dalam platform.

3. Keranjang Belanja

Pembeli dapat melihat secara rinci produk yang akan dibayarkan untuk diproses selanjutnya.

4. Ekspedisi

Ekspedisi merupakan sistem penting pada platform e-commerce untuk mengirim produk ke konsumen. Ekspedisi yang biasa digunakan adalah JNE, J\&T, Wahana, TIKI, dan lainnya.

Selain itu proses bisnis platform e-commerce juga didukung oleh media sosial seperti Instagram dan Facebook untuk memasarkan produk dan mengarahkan pembeli untuk menggunakan platform e-commerce dalam bertransaksi yang aman. Saat ini tidak hanya Instagram dan Facebook tetapi juga muncul media sosial baru seperti Tik Tok.

Sesi diskusi berlangsung dengan lancar. Beberapa pertanyaan kami terima dari mitra, diantaranya:

a. Bagaimana menentukan modal awal jualan online? (Penanya: Refrizal Hardiyanto). Jawaban: Pada pertanyaan ini kami menjelaskan bahwa modal awal untuk memulai jualan online adalah dengan mebukan Pre Order kepada konsumen dan memastikan konsumen melakukan pembayaran. Sebelum membuka Pre Order, penjual diharapkan sudah mempunyai agen online yang terpercaya. Agen online terpercaya tidak diperoleh dengan mudah sehingga sebelum memilihi penjual melakukan pembelian beberapa kali untuk dikonsumsi pribadi, langkah ini berguna untuk memastikan keamanan dan kebenaran dari keberadaaan toko tersebut. Seperti yang kita ketahuan bahwa bisnis 
online juga memiliki sisi buruk yaitu banyaknya toko yang digunakan untuk penipuan, sehingga sebagai pengusaha online yang baru saja menggunakan e-commerce harus memastikan keamanan barang benar-benar sampai ke konsumen sehingga penjual secara bertahap membangun pangsa pasar bagi produknya.

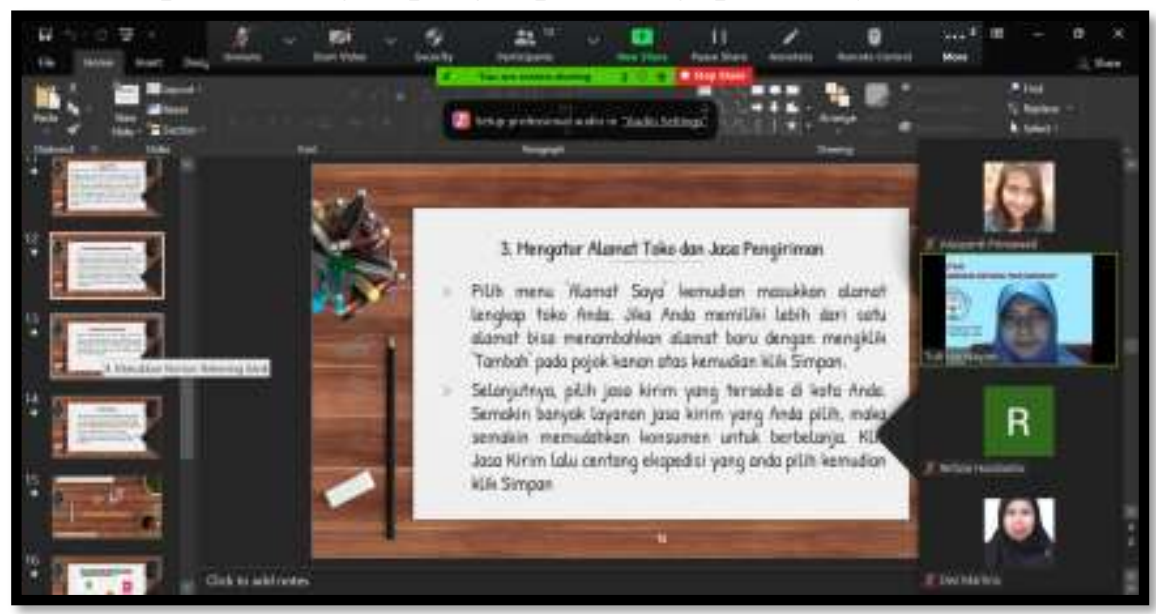

Gambar 3 Sesi 2 Sosialisasi dan Pelatihan Penggunaan Platform E-commerce

Platform e-commerce yang diperkenalkan adalah Tokopedia, Shoppe, Lazada, dan Bukalapak. Sedangkan media pemasaran melalui media sosial adalah Instagram, Facebook, dan lainnya. Selanjutnya adalah Gambar 4 yang menampilkan dokumentasi pada saat sesi diskusi kegiatan pengabdian masyarakat.

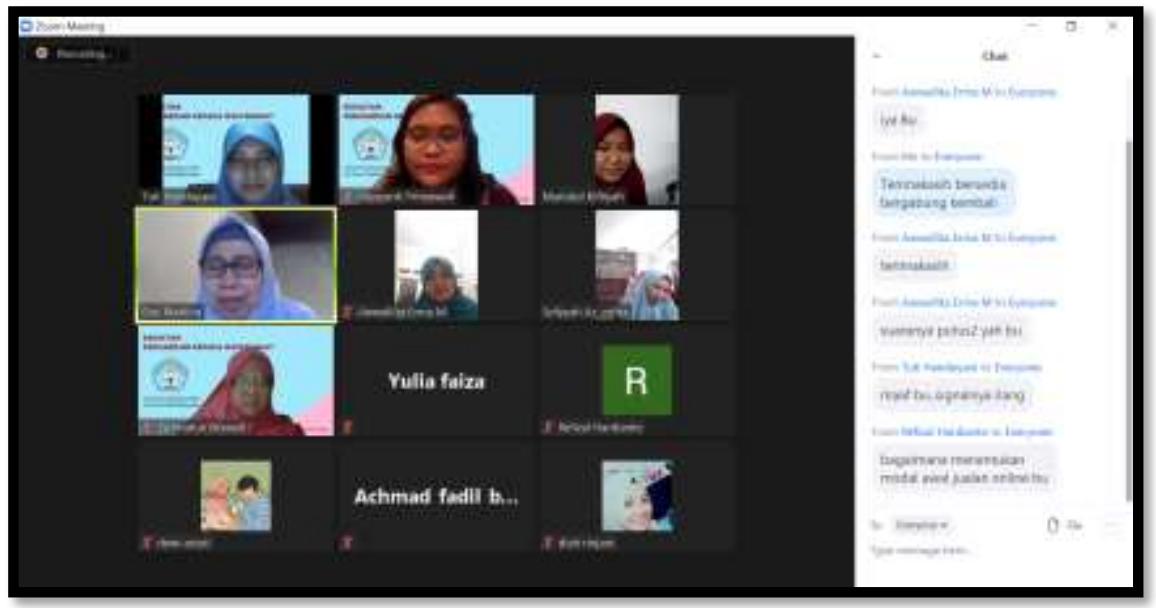

Gambar 4. Sesi Diskusi

Terlepas dari semua diskusi yang telah diselenggarakan, kepala sekolah menyampaikan kesimpulan bahwa pengetahuan tentang e-commerce pada masa pandemi ini merupakan hal yang baru dan menarik bagi mitra sehingga mitra memiliki pengetahuan bahwa e-commerce pada masa pandemi sangat bermanfaat khususnya untuk menambah pendapatan atau memulihkan perekonomian keluarga..

\section{Kesimpulan}

Kegiatan pengabdian masyarakat ini telah memberikan kontribusi yang positif bagi peningkatan pengetahuan dan skill dalam bidang teknologi informasi dalam upaya memudahkan kelompok pendidik seperti guru dan orang tua memperoleh pendapatan tambahan 
dalam rangka meningkatkan jiwa wirausaha di tingkat sekolah. Harapannya ilmu ini juga dibagikan ke para siswa sehingga generasi bangsa mulai berinovasi dan mengambil peran dalam perekomian negara. Berikut ini adalah beberapa simpulan dari hasil kegiatan yang sudah diselenggarakan bersama mitra dan tim pengabdian masyarakat:

1. E-commerce merupakan hal baru bagi mitra dan topik yang bermanfaat untuk menumbuhkan wirausaha bagi para guru atau orang tua siswa sehingga pada masa pandemi, mereka dapat menambahkan pendapatan atau memulihkan perekonomian keluarga.

2. Platform e-commerce seperti Tokopedia, Shopee, Bukalapak, dan lainnye secara umum sudah dikenal oleh mitra akan tetapi pemanfaatannya belum sampai pada kegaitan produktif melainkan konsumtif sehingga muncul keinginan memulai usaha akan tetapi seringkali memiliki kendala pada modal awal usaha.

Demi tercapainya tujuan dari kegiatan pengabdian masyarakat ini, maka kami memberikan rekomendasi kepada mitra sebagai berikut :

1. Perlu dilakukan pelatihan keamanan berjualan online dikalangan mitra baik guru atau orang tua.

2. Pada masa pandemi perlu melakukan inovasi dengan memanfaatkan teknologin internet secara optimal baik dalam pembelajaran atau pemenuhan kehidupan sehari-hari.

3. Perlunya meningkatkan keterampilan bagi mitra untuk menghasilkan produk yang kreatif dan memililki inovasi dibidang teknologi dan lainnya sehingga sejak dini para siswa juga memperoleh kemampuan mencipatakn produk baru yang memiliki nilai ekonomi tinggi.

\section{Daftar Pustaka}

Ayu, S., \& Lahmi, A. (2020). Jurnal Kajian Manajemen Bisnis. Jurnal Kajian Manajemen Bisnis, 9(September), 114-123. https://doi.org/10.24036/jkmb.10994100

Hadiwinata, K., Mundzir, H., \& Muslim, S. (2020). Analisis Peran Media Sosial Instagram sebagai Media Pemasaran dan Branding Bisnis di Era Pandemi Covid 19. SENABISMA, 6, 62-68.

Kaban, R. F., Hadiyati, P., \& Prihandini, W. (2020). Efektivitas Pemberdayaan E-Commerce Terhadap Peningkatan Wirausaha Santri. Jurnal Abdimas Perbanas (JAP), 1(1), 1-10.

Orinaldi, M. (2020). Peran E-commerce dalam Meningkatkan Resiliensi Bisnis diera Pandemi. Iltizam Journal of Shariah Economic Research, 5(2), 36-53.

Priyowidodo, G., Sari, Y. D., \& L, I. I. (2019). Pemberdayaan Perempuan Dalam Memahami Komunikasi Pemasaran Pada Media Online ( Konsep E-Commerce) di GPDI Sejahtera Junrejo Batu. SHARE (Journal of Service Learning), 5(1), 1-8. https://doi.org/10.9744/share.5.1.1-8

Sudaryono, Rahwanto, E., \& Komala, R. (2020). E-Commerce Dorong Perekonomian Indonesia, selama Pandemi Covid 19 sebagai Entrepreneur. Jurnal Manajemen Dan Bisnis (Jumanis), 02(01), 200-213.

Sugiarti, Y., Sari, Y., \& Hadiyat, M. A. (2020). E-Commerce untuk Meningkatkan Daya Saing Usaha Mikro Kecil dan Menengah (UMKM) Sambal di Jawa Timur. Kumawula: Jurnal Pengabdian Masyarakat, 3(2), 298-309. https://doi.org/10.24198/kumawula.v3i2.28181

Syamsidarti Laming. (2020). Tren E-Commerce pada Era Pandemi Covid-19. Jurnal Penelitian Humano, 11(02). 